\title{
The Mediator
}

Reviewed by Gaylene Kendrick.

The Mediator: A Life of Richard Taylor 1805-1873.

J. M. R. Owens.

Wellington: Victoria University Press, 2004.

In the Dictionary of New Zealand Biography, Vol 1, John Owens describes Richard Taylor as a missionary, naturalist and writer. On the surface he seems like just another missionary type, typical of the nineteenth century New Zealand story. He becomes more interesting perhaps because of the times within which he lived; pre Treaty through to post wars. More so, because he began his missionary career in the Far North and was involved at Waitangi with the historic signing of the Treaty. He also spent the majority of his life at Whanganui, arriving in 1843 with a young family in tow and remaining there until his death thirty years later. Whanganui was at this time an important part of the colonial story being a Wakefield settlement and situated at the crossroads of some major tribal groups. Furthermore the river was the main entrance to the interior and a major 'highway' for overland travel from Wellington to Auckland.

A scan of Taylor's contemporaries confirms his importance to the New Zealand story. Octavius Hadfield, Bishop Selwyn, William Yates and the Reverends Williams to name a few from the Anglican world, he also knew some of the Catholic clergy although sectarian prejudice on his part did not encourage closeness. Furthermore, he entertained and knew personally New Zealand and Australian Governors, such as Hobson, Eyre, Gore Browne and Grey. With Governor FitzRoy, Taylor was none too impressed mostly because his time as Governor was spent negotiating between Maori and settlers firstly in the Wairau and then in the Far North. He therefore had no time to engage with the troubles besetting Whanganui that Taylor was grappling with. Taylor expected more of him and thus was doubly impressed with Governor Grey when his reaction to a call for peace in the Whanganui resulted in an immediate visit by the Governor and his wife. Donald McLean had become quite a close friend of the Taylor family during his time as SubProtector of Aboriginies in Taranaki and had travelled with Taylor on trips into the interior. However, Taylor blamed him for the outbreak of war in Taranaki in 1860 and his friendship with him waned after this time.

Taylor became friendly in later life with William Fox and he knew the Wakefields. Taylor visited and at times stayed with $\mathrm{Te} \mathrm{Heu} \mathrm{Heu}$ the great Ngati Tuwharetoa chief and Hone Heke of Nga Puhi whom he always held in 
fond regard. He was on personal terms with all of the great Whanganui chiefs, from Hoani Hipango, Te Anaua, Te Mawae, Pehi Turoa and Topine Te Mamaku. Taylor was on the periphery of the developing King Movement in the 1850s. He knew and had met many of the main players such as Tamihana Te Rauparaha, Wiremu Tamihana and had attended at least one of the Kohimarama meetings. In fact this book reads like a veritable Who's Who of New Zealand in the nineteenth century.

Owens' biography allows us to indulge in a fascination with this stubborn and sometimes narrow minded man as we read of his role in race relations both locally around the Whanganui River region and nationally. It might be a surprise to discover that the fortifying of Wanganui town may well have occurred at his behest; that the saving of the town and its settlers had as much to do with his work as that of local Putikiwaranui Māori who sponsored him. Indeed it was for his work with and commitment to local Mãori that Taylor is remembered with much fondness. His personal mission to 'civilise' rather than 'Christianise' and his concern at keeping the peace led to considerable development of the local Māori economy, literacy and ultimately his role as mediator. His efforts in christianising Māori were also considerable although he had less success with the local Pākehā population.

Throughout the turbulence of the early settlement years of the Wanganui town and the developing years of the young nation, Richard Taylor kept an extensive diary reaching fourteen volumes. He published two books and it is as this reliable chronicler of events that Taylor inhabits a vital role as witness to the life and times of mid nineteenth century New Zealand.

John Owens' book The Mediator A Life of Richard Taylor 1805-1873 is as much about nineteenth century New Zealand. Indeed the two are inextricably entwined. Owens accepts the challenge to present both Taylor and history in this book and does a fine job. In fact I felt bereft when Taylor left New Zealand for the occasional visit to England and thus misses out on chunks of history in the making. This is not as bereft as I felt at the end of the book when Taylor succumbs to mortality in 1873 and we are left without a pilot to guide us through the remaining years of the century.

In addition to Taylor's role as mediator, the book provides a chronological journey through his formative years in Britain, his move into missionary work, marriage and then immigration to New Zealand. It is packed with photographs and sketches of Taylor and his family, the places he visited and the people he knew. Some of them are familiar but many provide a fresh look at this interesting man and his life.

Owens' work is largely based on Taylor's own writings, but is amply augmented by the diary of his daughter Laura, and formal correspondence between government and church officials. There is also a personal 
connection made with descendants who provide oral testimony and who made available photographs and memorabilia; in particular the cousins Richard and Dr Richard Taylor who clearly made a great impression on Owens.

The Mediator with its extensive research in New Zealand, Britain and Australia is a life's work for Owens and is a work of considerable passion. As a Missionary Historian, Owens has long had a particular interest in events and people surrounding the church and its work in New Zealand. Whilst he does address Taylor's short comings when he feels they should be mentioned, he never evaluates Taylor in an historical sense and we are left as readers trying to decide where this man fits into the big picture.

Taylor's empathy and understanding with Māori is evident early on, and it is clear that he is held in considerable regard by Māori of the Whanganui. It may be though that Taylor has a bigger role in the colonisation of the Whanganui than has hitherto been acknowledged and a final conclusion on his place in time is yet to be made.

Nonetheless, this book satisfies the reader on many fronts and one is most certainly left with a sense of who the Reverend Richard Taylor was and why he did what he did. This is a book that takes its place comfortably on the shelves of $19^{\text {th }}$ century New Zealand Histories and those focussed upon missionary work in the early contact period. 